\title{
ATHYSANELLA, A NEW GENUS OF JASSIDS.
}

BY CARL F. BAKER, ALA. POLYTECHN1C INST., ALBURN, ALA.

\section{Athysanella gen. nov.}

- Athysanus-like forms, small, pale fulvous, or grayish; and rather robust. Head wider than pronotum, vertex rather strongly, but very obtusely angulate, the usuatly convex and more or less transversely depressed vertex brondly rounded on to the front; at apex usually with two large and one small, black spots. Rostrum weak, shorter than clypeus. Clypeus broad, the sides very gradually converging to the rounded apex. Ocelli on extreme front edge of vertex and close to eyes. Front short and broad, conspicnously wider than clypeus at clypeal suture, the sides sinuate and slightly diverging upward. Lorae about one half width of clypeus or less, and of about the same length. Antennae about as long as bead and pronotum together. Pronotum transverse, about as long or shorter than vertex, feebly transversely wrinkled posteriorly and with a few faint punctures.

Usually brachypterous. In macropterous individuals the elytra abont equal the abdomen $i$ is length, with a broad appendix extending around the apex; with four apical cells including the one between the first anteapical and costa, which should perhaps not be called an apical; with two anteapical cells, the second a part of the basal cell cut off by the usual transverse vein which enters radial cell; the radial, first anteapical, and first true apical directly in line; the first true apical narrow, sides subparallel, the second and third true apicals broad, broadening apically. Wing with the short costal or supernumerary cell distinctly defined; with two apical cells, the second about half the width of first, the submarginal about haif the width of marginal. 'The ovipositor always long and strongly exserted. Type Athysanella magdalena $\mathrm{n}$. $\mathrm{sp}$.

This is a small group of closely related western forms, which will include together with several undescribed, Athysams curtipennis G. \& B., and Eutettix torebrans G. \& B. Of some of the species here placed in this genus, the fully winged forms are unknown, but other characters make their relationships very evident.

The head in this genus is much like that of Athysamus in many respects, though more produced than is usual in that genus The characteristic elytral and wing venation throw it at once into a group which includes Aconura, Gnathodus and Henschia. But it is very distinct from any of these. It should not be confused with that group of Deltocephalus which includes argenteolus and its allies. These are also dimorphic and possess the elongate ovipositor. It has only a superficial resemblance to Doratura, the head in that genus being totally different.

Athy'sanella magdalena n. sp. Macropterous female. Length $3.25 \mathrm{~mm}$. Front little more than one-fifth longer than broad, about twice the length of the clypeus. Clypens about one-fifth longer than broad. Vertex very obtusely angulate, broadly transversely depressed at middle, length on median 
line four fifths of width between the eyes. Pronotal breadth somewhat more than twice and a third the length, the latter slightly greater than that of the vertex. Elytra scarcely equalling the tip of the ovipositor.

Color pale sordid fulvous. Front with about seven dark transverse curved arcs on either side, sutures of front, clypeus, and lorae black. Front edge of vertex with a large more or less distinct black spot on either side of apex, and a small one at its extremity. Disc of vertex with a median transverse brown cloud on either side, and an acute black point springing from the hind margin on either side. Pronotum cinereous, lighter on anterior margin where there occur more or less distinct spots as follows : two approximate near median line, two behind each eye, and usually one elongate near the lateral margin. Scutel pale fulvous, basal angles and an irregular area on median portion darker. Elytra opaque, nervures whitish. Dorsum as in brachypierous female, of which see description below. Venter except portions of last segment blackish, pygofers each with a median longitudinal brown stripe. Abdomen sometimes suffused with a deeper black. Anterior and middle femora with a more or less distinct dark annulus near the knee.

Brachypterous female. Elytra not half Jength of abdomen, hind margin very broadly rounded, nearly truncate. Dorsum with three pairs of fine dark longitudinal lines, one median and two lateral, between these two or three black dots on each segment.

Last ventral segment of female twice the length of preceding, the hind margin deeply broadly emarginate, the emargination nearly filled by a large obtusely rounded tooth, which is narrowly black margined and about equals the lateral angles. Ovipositor about three fourths the length of the abdomen, exceeding pygofers by one third of its length.

Male. Length $3 \mathrm{~mm}$. My specimens are all macropterous. In many the black spots on apex of vertex are reduced in size and light brown. The abdomen excepting the plates is darker than is usual in the female, and more or less distinctly variegated with black and yellowish. The valve is about as long as the preceding segment and obtusely angulate, its disc hlack. The plates are three times the length of the valve, outer edges straight, inner edges gently curved outward to meet the outer edges in a rather acute point; each plate with a black spot at base.

Described from one female from the Magdalena Mountains, New Mexico, Aug. '94 (Snow), and numerous specimens from Colorado collected by myself at the following points :- Fort Collins, Aug. 2oth to Sept. Igth on Bouteloua oligostachya; Foothills west of Fort Collins, April 25th to May 6th; at Forrester's Ranch on the Upper Laramie River (elev. abont Sooo ft.) August $3 \mathrm{~d}$. This is apparently a common species in the West. One female from Colorado is much more strongly fulvous throughout and has the markings somewhat obscured.

Athysanella occidentalis n. sp. Brachyterous female. Length $3 \mathrm{~mm}$. Closely resembling mardalena. Front about as long as broad, once and a half the length of the clypeus. Clypeus one fifth longer than broad. Vertex obtusely angulate, slightly depressed posteriorly, lengtl at middle nearly equalling the width between eyes. Pronotal width twice and three fourths the length, the latter little more than four fifths that of the vertex.

Color sordid fulvous, darker beneath. Head marked as in magdalena. Pronotum somewhat cinereous, in front medially with four black spots in a transverse row, and laterally two behind each eye. Dorsal segments each with a median transverse row of 
about eight black dots, medially and laterally with indistinct pairs of longitudinal lines; base of terminal segment black. Venter except edges of pygofers, very dark. Fore and middle femora obscurely annulate with brown.

Last ventral segment a little longer than preceding, hind margin slightly roundly produced at center, laterally sloping. Ovipositor extending one fifth of its length beyond the pygofers. Pygofers with a few white hairs at extremity.

In macropterous females the elytra do not differ from those of magdalena, except that toward the apex the white veins are distinctly narrowly bordered with brown.

\section{Described from ten females collected} by myself at Fort Collins, Colo., and in the adjoining foothills, from April 23 d to July is.

Athysanclla acuticauda n. sp. Brachypterous female. Length $3.5 \mathrm{~mm}$. Resembles occidentalis in coloration, but is stouter. Front about as broad as long, once and three fifths the length of the clypeus. Clypeus one fourth longer than hroad. Vertex very obtusely angulate, slightly depressed posteriorly, length at middle three fourths of width between the eyes. Pronotal width twice and three fourths the length, the latter four fifths that of the vertex.

Color as in occidenfalis, except that on the pronotum there are but two median spots. Venter darkened at base, a broad median portion of last ventral segment and a longitudinal line on each pygofer, black.

Last ventral segment a half longer than preceding, hind margin truncate or wightly sinuate, the lateral angles slightly roundly projecting; the ovipositor extending one sixth of its length beyond the pygofers.

Macropterous female. Elytra deep fuliginous, the veins yellowish, sharply contrasted.

Brachypterous male. Valve as in magda- lema, plates very short, subtriangular, bent outward and widely diverging.

Described from nine females and one male. The single male was collected at Algonquin, Ill., Aug. Ist. (Dr. IV. A. Nason). The females are distributed as follows: Algonquin, Ill., July zoth (Nison); Toronto, Canada, (R. J. Crew and C. T. Hills); and at the following localities in Northern Colorado, collected by myself: Foothills near Fort Collins, June zoth to Aug. $4^{\text {th }}$ and at various points in the mountilins up to IISoo feet altitude at Cameron Pass.

Athysanellu, robusta n. sp. Brachypterous female. Length $4 \mathrm{~mm}$. Form nearly of acuticauda. Front very little longer than broad, once and four fiths the length of the clypeus. Clypeus one sixth longer than broad. Vertex broadly tumidly rounded in front, slightly depressed posteriorly, length at middle two thirds of the width between the eyes. Pronotal widtl twice and four fifths the length, the latter little less tham that of the vertex.

Color pale fulvous; markings as in acuticauda, except that the vertex has only a small comma shaped brown dot on either side half way between eye and apex, the large black spots being absent. Elytra cinereous, with five brown dots along apical border.

Last ventral segment of the same length as preceeding, broadly emarginate with a large rounded shining black tooth nearly filling the emargination and equalling the lateral angles. Ovipositor exceeding the pygofers by little less than one fifth of its length.

Brachypterous male. Valve black, narrowly edged with yellowish, plates short, 
about as long as wide, inner margin straiglit, outer margin at the apical two thirds incurved to the obliquely truncate apex, which is very slightly emarginate.

This is also a Northern Colorado inhabitant. The three males before me were collected in the foothills west of Fort Collins, Aug. $4^{\text {th. }}$. One of them is slightly larger than the others and distinctly suffused with reddish, but it has the peculiar plates of the others. The females are also from the lower foothills, taken May 6th to July zist.

Athysanella attenuata n. sp. Brachypterous female. Length $5 \mathrm{~mm}$. This species resembles terebrans and cuvtipennis and is the largest most robust representative of the genus. Front a twelfth longer than broad, about twice the length of the clypeus. Clypeus one fourth longer than broad. Vertex very obtusely angulate, transversely depressed posteriorly, length at middle fiveseventlss of width between eyes. Pronotal width twice and a third the length, the latter equaling that of the vertex.

Color very pale fitlvous, brighter below, tip of ovipositor reddish. Vertex and face with the markings usual to this genus. Pronotal dots subobsolete. Elytra cinereous. Dorsum with indications of lateral lines, and with a double median longitudinal row of black dots; last segment black at base.

Last ventral segment twice the length of preceding, medially broadly black, the hind margin truncate or very slightly trisinuate. Ovipositor exceeding the pygofers by little less than one-third of its length.

Brachypterous male. Length $3.25 \mathrm{~mm}$. Darker throughout than the female. Valve longer than the preceding segment, triangular, the apical portion somewhat narrowed. Plates triangular, twice the length of the valve and rather strongly diverging.
Described from four males and many females collected by myself in Northern Colorado. It occurs at Fort Collins throughout the summer season and I have also taken it at Forrester's Ranch, on the Upper Laramie River on Aug. 3 rd.

Athysanella incongrua n. sp. Brachypter. ous male. Length 3.2.5. Front one seventh longer than broad, a little less than twice the length of the clypeus. Clypeus one fourth longer than broad. Vertex very obtusely angulate, broadly depressed posteriorly, length at middle six sevenths of the width between the eyes Pronotal width twice and a third the length, the latter less than that of the vertex.

Color very pale fulvous, head, pronotum, and abdomen with a distinct rosy tint, especially on the last. Arcs on front indistinct. Vertex, just before apex, with two small brown closely approximated dashes, one on either side of a white median line; a small black dot on either side of this, near the front margin. Pronotum anteriorly with two minute median dots, and three behind each eye. Dorsum with indications of median and lateral lines, each segment with a transverse row of about ten distinct black dots; the last segment blackish at base. Apical margins of ventral segments blackened.

Valve shorter than the preceding segment, broadly rounded, disc dark. Plates about twice length of valve, somewhat diverging, and gradually narrowed to a truncate tip.

Described from one specimen collected by myself in the foothills west of Fort Collins, Colo., July 21 st. There is no female in my collection with which I can associate this. It somewluat resembles the $\delta$ of attennata, but differs widely in color of head and in genital characters. 
Athysarella minuta n. sp. Brachypterous female. Length $2.5 \mathrm{~mm}$. The smallest and darkest species in the genus, though the head and pronotum are nearly as broad as in magialena, which it somewhat resembles. Front about a tenth longer than wide, once and five sixtlas the length of the clypeus. Clypeus one-fourth longer than bjoad. Vertex very obtusely angulate, slightly transversely depressed posteriorly, length little more than five sevenths of width between eyes. Pronotal width twice and one half the length, the litter less than that of the vertex.

Color sordid fulvous. Head markings as in magdalena, but daker. Pronotum with four dots near middle, the two inner darker, and with three behind each eje. Abdomen quite obscured and dark throughout.
Last ventral segment slightly longer than the preceding, hind margin evenly truncate. Oripositor exceeding pygofers by less than one sixth of its length.

Brachypterous male. Length $2 \mathrm{~mm}$. Venter except lateral margins black. Valve large, convex, very broadly rounded, deep black with a fine yellow margiu. Plates yellowish, extending less than the length of the valve beyond it. Beyond the valve the plates are equilaterally triangular, the inner margins diverging.

Descriled from one female and two males collected by myself at Fort Collins, Colo., June $7^{\text {th }}$ to Aug. 6 th and at Forrester's Ranch, on the Upper Laramie River. Colo., Aug. 3rd.

\section{DESCRIPTION OF A NEW SPECIES OF ARCTIIDAE WITH TABLE OF THE SPECIES OF IDALUS.}

BY HARRISON G. DYAR, WASHINGTON, D. C.

Idalus fichcsensis n. sp.- Head white, a large deep yellow spot on the vertex and the upper halt of the front black, palpi black above and at tip. Thorax white collar broadly lined behind with crimson and the patagia less distinctly bordered with this color; a deep yellow patch in center of thorax with two black dots before and two behind; a yellow patch in the center of each patagium. Abdomen crimson above with a dorsal row of indistinct white spots. Below white, fore coxae inwardly, posterior orbits and a tuft below fore wing crimson; fore femora and tibiae shaded with gray, middle femora much less so, tire middle and posterior tibiac with a black spot at tip. Fore wing thinly scaled outwardly, slightly irridescent, deep yellow, costa and fringe white; discal band black, straiglst, a little narrowed centrally, ending at costa and margin, cut with white by all the veins and centered by the discal cross vein, bordered with white on both sides except centrally. Basal patch similar, broadest at internal maryin (the yellow median space thus much widest on costa;, black, cut by white veins. Secondaries white. Below no markings except a few dusky scales on discal cross vein of fore wings. Expanse 44 mm.

1 f Piclies and Perene vols., Perv, 2000$3000 \mathrm{ft}$.(Soc. Geog. de Lima). U. S. Nat. Museum, type no. 3796.

\section{Table of species of Idalus.}

1. Primaries with a dark spot outwardly between vein 5 and $6 . .2 .2$

Primaries with terminal field immaculate

2. Discal band which crosses wing broken only by the veins . . . . 3 

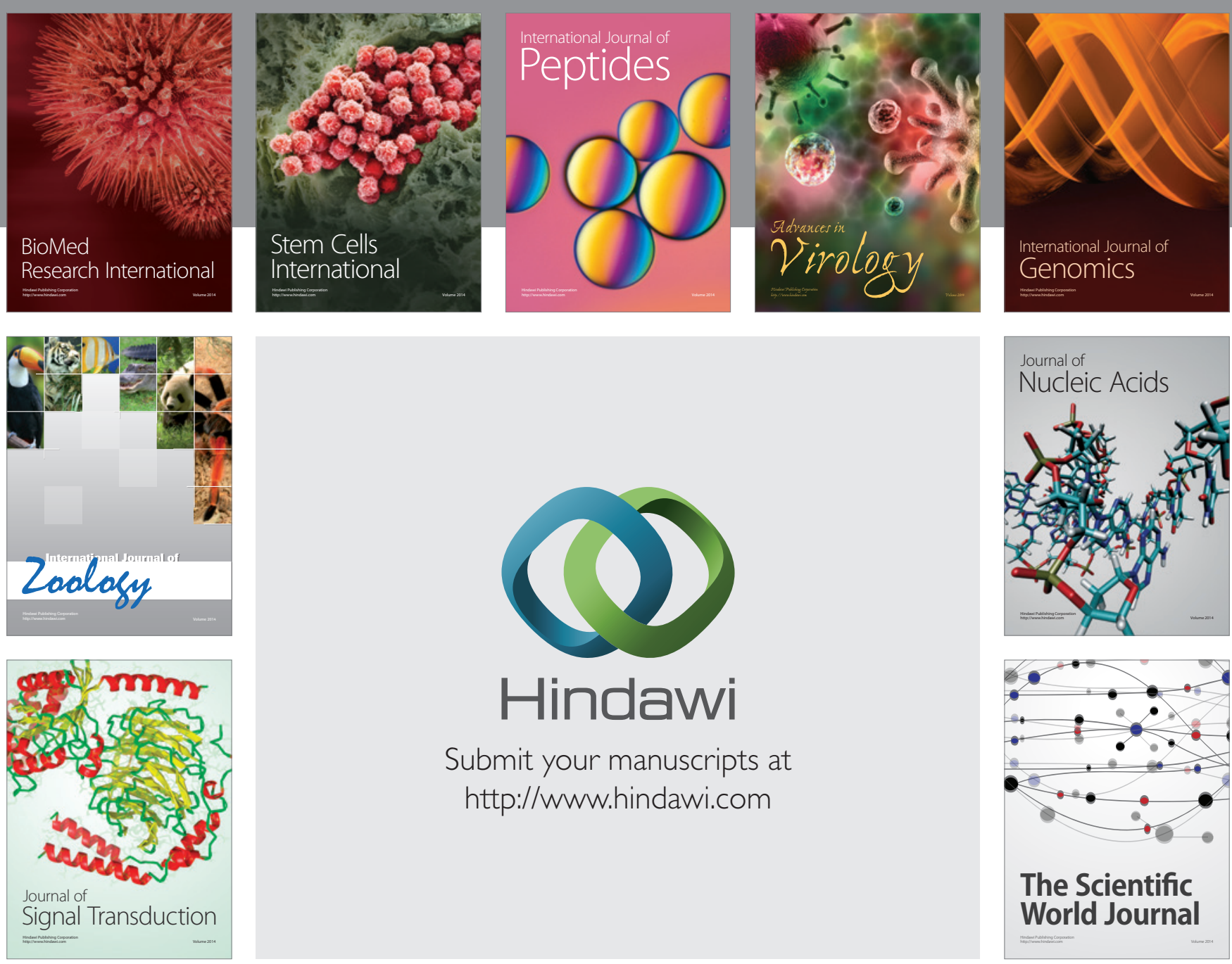

Submit your manuscripts at

http://www.hindawi.com
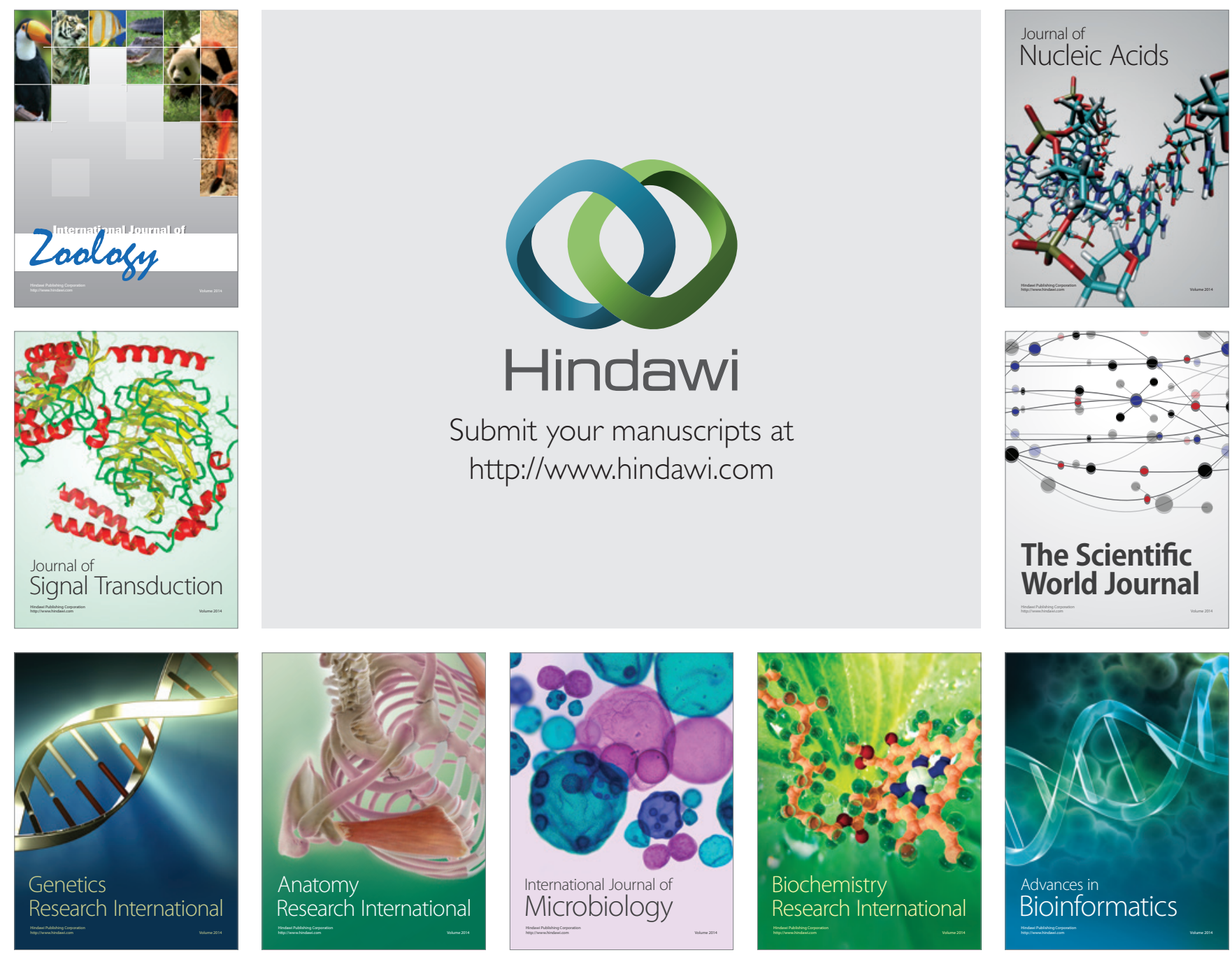

The Scientific World Journal
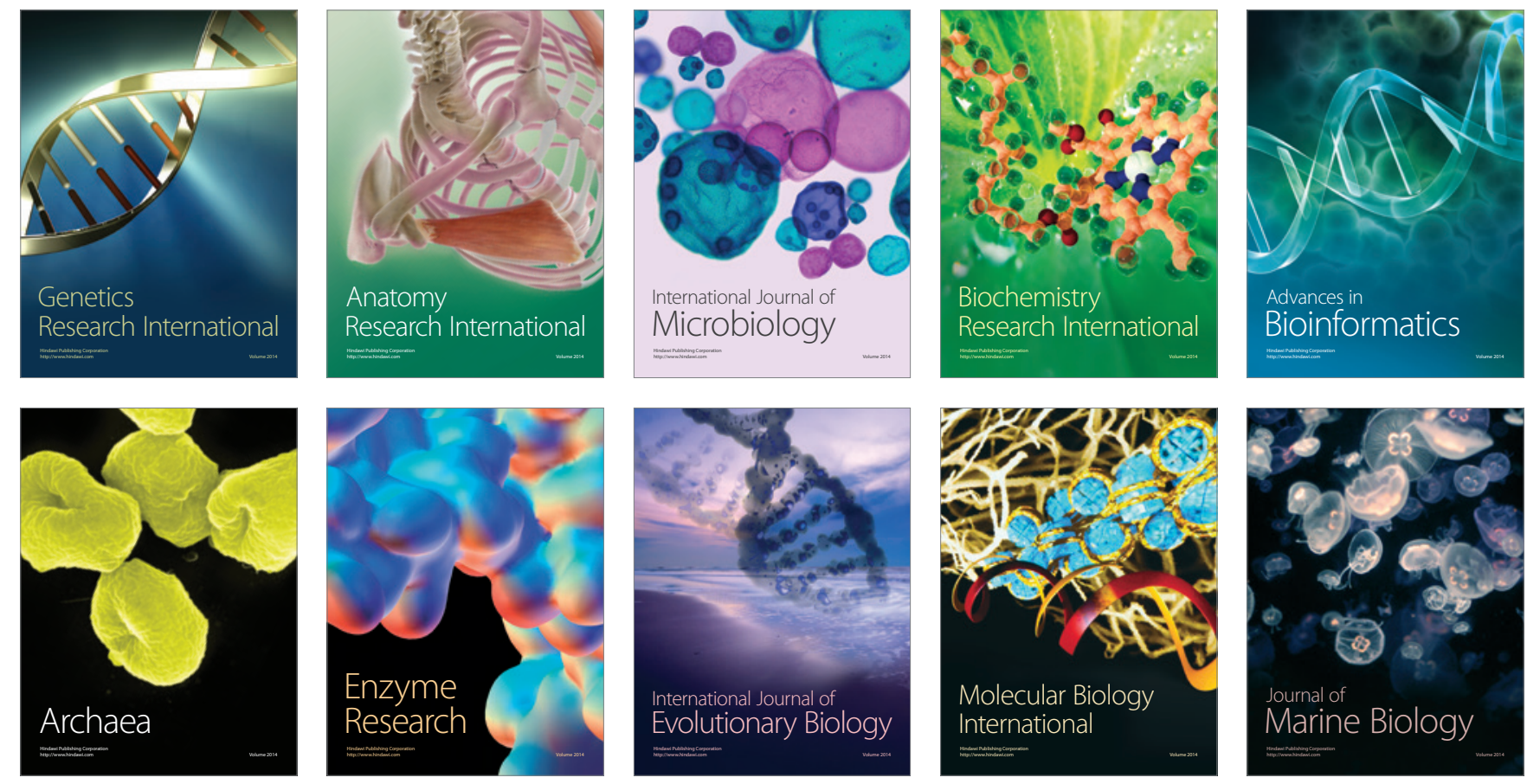